\title{
Superficial Surgical Site Infection after Colorectal Surgery: Targeting High-Risk Patients Increases the Efficacy of Prevention Bundles
}

\author{
Kolorektal Cerrahi Sonrası Yüzeyel Cerrahi Alan İnfeksiyonu: Yüksek Riskli \\ Hastaların Hedeflenmesi Önlem Demeti Etkinliğini Arttırır
}

\author{
Ahmet Rencüzoğulları, Joseph A. Trunzo, Jon D. Vogel, Dilara Khoshknabi, Luca Stocchi, Emre Görgün \\ Cleveland Clinic, Department of Colorectal Surgery, Ohio, USA
}

\section{HIIIIII ABSTRACT}

Aim: To reduce surgical site infections (SSI) after colorectal surgery, applying prevention bundles to all patients is expensive and has minimal success. The aim of this study is to identify factors associated with high-risk of superficial SSI (SSSI) and to assess the impact of prevention measures on highrisk patients.

Method: Between January 2010 and February 2014, patients who underwent colorectal surgical procedures were identified as pre-bundle (January 2010 and July 2012) and bundle (August 2012 and February 2014) period. Factors associated with SSSI risk were evaluated. Pre-bundle and bundle patients were categorized in deciles from low- to high-risk using a risk model. The impact of prospectively introduced protective measures was assessed in the bundle patients with multivariate modeling and frequency-matched analysis.

Results: There were pre-bundle 2,535 patients who underwent ileocolic (19.1\%), left-sided (46\%), and pelvic (34.9\%) procedures. Overall SSSI rate was $10.7 \%$. Four patient-related factors and five procedure-related factors were found to be significantly associated with SSSI on unadjusted analysis. Comparison of pre-bundle patients on whom the risk model was built and the bundle patients used in the risk assessment showed significant decrease in SSSI rates $(10.6 \%$ to $3.2 \%$, p $<0.001)$. Frequency matched analysis demonstrated a significant reduction in SSSI from pre-bundle to bundle patients ( 13.1 to $4.2 \%, \mathrm{p}<0.001$ ). Among the risk deciles in bundle patients, the reduction from the average predicted risk to the observed SSSI rate was most evident among the high-risk groups.

Conclusion: Preventive strategies specifically aimed at patients with the highest risk for SSSI after colorectal surgery resulted in the highest reduction. Considering the variability of SSI rates, collaborative and targeted policies are critical to ensure efficacious and potentially cost-effective strategies.

Keywords: Superficial surgical site infection, prevention bundle, colorectal surgery, high-risk patients

\section{||||||||| ÖZ}

\begin{abstract}
Amaç: Kolorektal cerrahi sonrası cerrahi alan enfeksiyonlarını (CAE) azaltmak için hazırlanan önlem paketlerinin tüm hastalara uygulanması pahalı olup minimal başarıya sahiptir. Bu çalışmada yüksek riskli yüzeyel CAE'leri ile ilişkili faktörler ve koruyucu önlemlerin yüksek riskli hastalardaki etkinliğini değerlendirmek amaçlanmıştır.

Yöntem: 2010-Ocak ve 2014-Şubat tarihleri arasında kolorektal eksizyon uygunlanan hastalar önlem demeti öncesi (2010 Ocak-2012 Ağustos) ve demet dönemi (2012 Ağustos-2014 Şubat) olmak üzere identifiye edildi. Yüzeyel CAE riski ile ilişkili faktörler değerlendirildi. Demeti öncesi ve demet dönemi periyoduna ait hastalar risk modeli oluşturularak 1/10'luk gruplar şeklinde düşük riskten yüksek riske doğru kategorize edildi. Demet dönemi periyoduna ait hastalara prospektif olarak uygulanan koruyucu önlemlerin etkisi çok değişkenli modelleme ve frekans-eşlemeli analiz ile değerlendirildi.

Bulgular: İleokolik (\%19,1), sol taraflı (\%46) ve pelvik prosedür (\%34,9) yapılan 2535 demeti öncesi hasta analiz edildi. Ortalama yüzeyel CAE oranı \%10,7 idi. Ayarlanmamış analize göre 4 hasta ilişkili ve 5 prosedür ilişkili faktör yüzeyel CAE ile anlamlı düzeyde ilişkili bulundu. Üzerinde risk modellemesi yapılandırılan demeti öncesi ve koruyucu önlemlerin uygulandığı risk değerlendirilmesinde kullanılan demet dönemi periyodu hastaları kıyaslandığında yüzeyel CAE oranlarında anlamlı düşme sağlandı (\%10,6'dan \%3,2'e, p<0,001). Frekans-eşlemeli analizinde demet dönemi periyodu hastalarında demeti öncesine kıyasla yüzeyel CAE'de anlamlı azalma tespit edildi (\%13'ten \%4,2'e, p<0,001). Demet dönemi hastalarına ait her 1/10'luk grupta, predikte edilen ve gözlenen yüzeyel CAE oranlarındaki düşme en belirgin şeklilde yüksek riskli gruplarda mecuttu.

Sonuç: Koruyucu stratejilerin kolorektal cerrahi sonrası yüzeyel CAE için yüksek risk barındıran hastaları hedeflemesi CAE oranında en fazla oranda azalma ile sonuçlanmıştır. CAE'lerin karmaşı natürü düşünüldüğünde işbirliği ile yapılan ve hedeflenmiş tedbirlerin uygulanması, etkili ve potansiyel olarak maliyet etkin stratejilerin sağlanmasında kritik öneme sahiptir.
\end{abstract}

Anahtar Kelimeler: Yüzeyel cerrahi alan enfeksyonları, önlem demeti, kolorektal cerrahi, yüksek riskli hastalar 


\section{Introduction}

Surgical site infections (SSIs) result in considerable morbidity, prolonged hospitalization and increased mortality risk among surgical patients. ${ }^{1,2,3,4}$ It contributes to significant financial burden on the health care system as the median cost for a single SSI-related readmission is calculated to be $\$ 12.835{ }^{5,6}$ Due to the nature of the colorectal flora, the risk of SSIs is consistently higher in colorectal surgery patients with a range of $5 \%$ and $45 \% .^{1,2,4,7,8}$ To ensure better clinical outcomes, SSI reduction efforts are being increasingly incorporated into the quality-improvement strategies., 2,5 As SSI has becoming the most frequent complication after colorectal procedures, identification of the best practice for the standardized care has paramount importance. ${ }^{5}$ Due to the multiplicity of the underlying etiologic mechanisms a single preventative approach is unlikely to decrease SSI rates. ${ }^{1,7}$ The use of preventive bundles, defined as "a set of interventions that, when performed together, promote best outcomes with a greater impact than if performed individually" has gained popularity as a way to address high SSI rates. Despite some deviations in components, bundles applied to all patients might have limited success ${ }^{4,10,11,12,13}$ and may not be costeffective. Recently released reports with increased SSI rates even after implementation of the intervention bundle $e^{4,11}$ rendered the routine implementation of bundles to all patients controversial. With the consideration of factors associated with infection differed based on the type of surgical site and more complex mechanisms are responsible for organ-space SSI, investigation of superficial component only can be considered as surrogate marker to analyze bundle effect. This clinical quandary inspired us to analyze whether stratifying the patients based on superficial SSI (SSSI) risk followed by targeting high-risk patients is effective or not. The aim of this study is to identify factors associated with a high-risk of SSSI and to assess the impact of a prevention bundle targeted in patients with these high-risk factors.

\section{Materials and Methods}

This was a retrospective cohort study consisting of patients who underwent small bowel, colon, or rectal surgery requiring resection at the Cleveland Clinic, Clinic of Colorectal Surgery, Ohio, USA. Data were acquired from an institutional review board-approved, prospectively maintained institutional database. The requirement for informed consent was waived by the institutional review board due to minimal risk of using protected health information. The database was queried to identify patients who developed SSSI and associated risk factors during the study period. SSSI was defined as an infection that occurred within 30 days after the operation, and that which involved only skin or subcutaneous tissue of the incision. Classifications of operative wounds were made according to the degree of microbial contamination; clean, contaminatedclean, contaminated and dirty. Patients in whom the skin and subcutaneous tissues were left to heal secondarily were also excluded from the study.

\section{Statistical Analysis}

The study cohort consisted of all patients undergoing open, laparoscopic, and robotic colorectal surgery by a total of 23 surgeons from January 2010 to February 2014. The SSSI-related outcomes after implementation of the bundle (Bundle: August 2012 and February 2014) were compared with the time period immediately prior to the implementation of bundle elements (Pre-bundle: January 2010 and July 2012). Unadjusted associations between demographics, surgical factors and SSSI were assessed using logistic regression analyses among the larger cohort of cases that preceded the SSSI prevention bundle. Among the pre-bundle patient population, factors identified as having significant unadjusted associations with SSSI at a 0.10 level, and patients for whom completed data was available with a rate of $100 \%$ for all the factors, were used to construct a multivariable logistic regression model for predicting SSSI risk. To assess calibration of the model, concordance index and Hosmer-Lemeshow for goodness of fit were applied. The relaxed significance level of 0.10 was chosen to allow identification of factors even with modest potential to carry an SSSI risk. Trends in SSSI over the pre-bundle period were investigated using a time component added to the model and with Lowess Smoothed fits of model residuals over time. As a second step, the model was then applied to the set of bundle patients, from August 2012 through February 2014, who underwent the designated protective measures and had complete information for the prediction model covariates, in order to determine their pre-bundle risk (i.e. the risk that would be expected for these patients if they had been treated in the pre-bundle period). The bundle patients were placed in order of predicted pre-bundle risk of SSSI and then grouped into deciles ranging from low- to high-risk patients. Within each risk decile, we summarized the average pre-bundle predicted risk of SSSI of the bundle patients, and compared it to the observed percentage of SSSI, using a two-sided p-value based on the binomial probability distribution. To further assess the reduction in SSSI between the pre-bundle and bundle periods, a 3:1 frequency matched set of patients was constructed based on wound class (clean and clean/contaminated vs. contaminated and dirty), surgical approach (laparoscopic vs. open), and BMI group $(<20,20-25,25-30,30-35, \geq 35)$. The analyses and graphs were produced using R version 2.15.1 (www.R-project.org). 
Continuous variables are presented as mean $\pm \mathrm{SD}$; categorical variables are expressed as numbers and percentages.

\section{The Preventive Surgical Site Infection Bundle}

A systematic approach to improve the use of SSSI preventive measures of perioperative care was used in constructing the bundle. Our bundle elements included operative components selected from a set of evidence-based preventive measure $e^{4}$ and were chosen according to purposes of practical and simple usage in daily surgical practices. The bundle used in this study consisted of three elements: use of a wound edge protector (Applied Medical, Rancho Santa Margarita, CA), bowel preparation using polyethylene glycol $3350 \mathrm{~mL}$. Percutaneous endoscopic gastrostomy (PEG) and oral antibiotics. Patients who received PEG were instructed to take clear liquids on the day of preparation, to begin the PEG lavage solution at 3:00 p.m., and complete it at 7:00 p.m. Oral antibiotic bowel preparation consisted of $2 \mathrm{~g}$ of neomycin and $2 \mathrm{~g}$ of metronidazole administered at 7:00 p.m. and 11 p.m. on the day preceding surgery. Our intravenous antibiotic prophylaxis for colorectal procedures was a combination of ampicillin/sulbactam that was administered 1 hour before surgery. None of pre-bundle patients were exposed to all measures implemented. The bundle program was coordinated by colorectal surgeons, quality director, and research nurses. Surgical cases from August 2012 through February 2014 for which the bundle program was employed were identified, and data collected in order to allow comparison of the actual occurrence of SSSI among such patients to the likelihood of SSSI that would be expected if the bundle program had not been developed.

\section{Data Collection and Surveillance}

The following demographic and clinical data were collected: patient age, gender, body mass index (BMI), serum albumin, specific co-morbidities, steroid use, immunosuppression, American Society of Anesthesiologists classification, and operative diagnosis (i.e. diverticulitis, colon cancer, inflammatory bowel disease). Surgical factors investigated included: mechanical bowel preparation, antibiotic utilization, use of a wound edge protector, location of resection (i.e. left colon, right colon and rectum), surgical approach (laparoscopy vs. open), emergency surgery and duration of surgery and process measures for improvement. In terms of definitions, National Surgical Quality Improvement Program abstraction guidelines were used for SSI classification (superficial, deep, or organ space) and operative wound classes (I, II, III, IV). As recommended by the Centers for Disease Control and Prevention for effective monitoring of institutional SSI incidence we rigorously monitored SSSI occurrence within 30 days. ${ }^{14}$ Postoperative data (through discharge) were meticulously collected by nurses who were responsible for postoperative standard care during hospitalization. Postoperative data (discharge through postoperative day 30) were extracted from the patients' electronic medical records.

\section{Results}

The study group included 2,535 pre-bundle patients who underwent ileocolic (19.1\%), colon (46\%), and rectal $(34.9 \%)$ resections. Of these, there were 272 (10.7\%) reported occurrences of SSSI. Table 1 shows the clinical characteristics and demographic features of the pre-bundle patient population. The mean age of the study group was $51.7 \pm 18$ years. The pre-bundle study cohort consisted of a slight male predominance with 1.274 (50.5\%) patients. Mean BMI was $27.2 \pm 6.5 \mathrm{~kg} / \mathrm{m}^{2}$. Four patient-related factors (BMI, diabetes, chronic obstructive pulmonary disease, and preoperative chemotherapy) and five procedure-related factors (open surgical approach, wound classification III-IV, transfusion, emergency surgery and operative time) were found to be significantly associated with SSSI $(\mathrm{p}<0.10)$ on bivariate analysis. These factors were used to construct a multivariable risk-adjusted model in a subset of pre-bundle 1408 patients who were considered eligible due to available data (Table 2). Open surgical approach [odds ratio (OR) 2.15; 95\% confidence interval $(\mathrm{CI}), 1.27-3.60 ; \mathrm{p}=0.004)$, wound class III-IV (OR 13.2; 95\% CI, 8.36-21.0; p<0.001) and BMI (OR 1.30; 95\% CI, 1.14-1.49; <0.001) were found to be independent risk factors for SSSI occurrence. Out of the 1408 pre-bundle patients, the risk-adjusted model showed an average predicted SSSI risk of $10.6 \%$. As expected, this predicted risk corresponded to an observed SSSI occurrence of $10.6 \%(\mathrm{n}=149)$. The 1408 patients on which the model was built were categorized into ten deciles in order of predicted probability of SSSI ( $\mathrm{n}=140$ or 141 per decile) and ranked from lowest to highest risk of SSSI by using the multivariable risk-adjusted model, which we had created. The concordance index for this model was 0.75 , and there was so significant evidence of lack of fit (Hosmer-Lemeshow $\mathrm{p}=0.33$ ). The presence of a long-term monotonic trend (not accounted for by model variables) was assessed by considering a linear time trend variable added to the pre-bundle model and found not to be statistically significant $(\mathrm{p}=0.20)$. We also assessed the possibility of short-term trends using smoothed fits of model residuals as a function of time. No time periods with markedly increased or decreased mean residual values were discerned over the course of the pre-bundle period Within each decile, average model predicted risk was nearly equal to the observed SSSI occurrence, demonstrating that the model was effective in fitting the pre-bundle data (Figure 1). Table 3 shows the comparison between pre-bundle and bundle patients. Two groups were comparable with respect 
to patient characteristics. All patients in the bundle period were exposed to all prospectively designated measures with greater than $98 \%$ compliance rate. However, in the pre-bundle period most of the bundle elements were not utilized. Only mechanical bowel preparation was used at surgeons' discretion in the pre-bundle period. Out of 625 bundle patients, 498 were used in prediction assessment due to having $100 \%$ completed data. The pre-bundle SSSI rate of $10.6 \%$ was notably higher than the bundle rate of $3.2 \%$ ( $\mathrm{p}<0.001$ ), as was the bundle average predicted risk of SSSI of $25.0 \%(\mathrm{p}<0.001)$. The bundle group $(\mathrm{n}=498)$ was categorized into deciles in order of predicted probability of SSSI ( $\mathrm{n}=49$ or 50 in each of the deciles) and ranked from lowest to highest risk of SSSI by using the multivariable risk-adjusted model

Table 1. Baseline patient demographics and comorbidities between the patients who developed SSI and those who did not among pre-bundle patients

\begin{tabular}{|c|c|c|c|c|}
\hline & $\begin{array}{l}\text { Overall } \\
(n=2535)\end{array}$ & $\begin{array}{l}\text { Superficial SSI (-) } \\
(\mathrm{n}=2263)\end{array}$ & $\begin{array}{l}\text { Superficial SSI (+) } \\
(\mathrm{n}=272)\end{array}$ & P-value \\
\hline $\operatorname{Age}^{¥}$ & $51.7 \pm 17.5$ & $51.6 \pm 17.7$ & $53.0 \pm 15.43$ & 0.2 \\
\hline Female gender & $1249(49.5 \%)$ & $1109(49.2 \%)$ & $140(51.7 \%)$ & 0.45 \\
\hline $\mathrm{BMI}^{¥}$ & $27.2 \pm 6.5$ & $27.0 \pm 6.4$ & $29.2 \pm 6.9$ & $<0.001$ \\
\hline \multicolumn{5}{|l|}{ Diagnosis } \\
\hline Cancer & $565(22.3 \%)$ & $504(89.2 \%)$ & $61(10.8 \%)$ & \multirow{4}{*}{0.85} \\
\hline Inflammatory bowel disease & $827(32.6 \%)$ & $742(89.6 \%)$ & $85(10.4 \%)$ & \\
\hline Diverticulitis & $224(8.8 \%)$ & $194(86.6 \%)$ & $30(13.4 \%)$ & \\
\hline Other Benign Diseases \& & $616(24.3 \%)$ & $551(89.4 \%)$ & $65(10.6 \%)$ & \\
\hline \multicolumn{5}{|l|}{ Wound Class } \\
\hline Clean/Contaminated & $2081(91.4 \%)$ & $1916(94.6 \%)$ & $165(66.0 \%)$ & \multirow{3}{*}{$<0.001$} \\
\hline Contaminated & $188(8.3 \%)$ & $104(5.1 \%)$ & $84(33.6 \%)$ & \\
\hline Dirty/Infected & $6(0.26 \%)$ & $5(0.25 \%)$ & $1(0.40 \%)$ & \\
\hline \multicolumn{5}{|l|}{ Surgical approach } \\
\hline Laparoscopic & $598(23.6 \%)$ & $563(24.9 \%)$ & $35(12.9 \%)$ & \multirow{2}{*}{$<0.001$} \\
\hline Open & $1937(76.4 \%)$ & $1700(75.1 \%)$ & $237(87.1 \%)$ & \\
\hline Operative time, min & $180 \pm 91$ & $178 \pm 90$ & $196 \pm 102$ & 0.02 \\
\hline Estimated blood loss, mL & $201 \pm 215$ & $193 \pm 207$ & $312 \pm 287$ & 0,007 \\
\hline Intra-operative blood transfusion* & & $195(8.6 \%)$ & $35(12.9 \%)$ & 0.02 \\
\hline Hospital stay, days & $9.3 \pm 7.4$ & $9.0 \pm 7.2$ & $12.0 \pm 8.6$ & $<0.001$ \\
\hline $\mathrm{DM}^{€}(\mathrm{n}=1402)$ & $211(15.0 \%)$ & $178(14.3 \%)$ & $33(21.2 \%)$ & 0.03 \\
\hline $\mathrm{HTN}^{\alpha} \quad(\mathrm{n}=2085)$ & $675(32.4 \%)$ & $594(32.0 \%)$ & $81(35.8 \%)$ & 0.24 \\
\hline $\mathrm{COPD}^{\oplus}(\mathrm{n}=1767)$ & $24(1.4 \%)$ & $18(1.1 \%)$ & $6(3.0 \%)$ & 0.04 \\
\hline $\operatorname{ESRD}^{\beta}(n=2031)$ & $6(0.30 \%)$ & $3(0.17 \%)$ & $3(1.4 \%)$ & 0.01 \\
\hline Emergency surgery & $65(2.6 \%)$ & $53(2.3 \%)$ & $12(4.4 \%)$ & 0.045 \\
\hline Recent chemotherapy ${ }^{\#}(\mathrm{n}=2025)$ & $67(3.3 \%)$ & $55(3.0 \%)$ & $12(5.4 \%)$ & 0.07 \\
\hline Recent radiotherapy ${ }^{\#}(\mathrm{n}=2025)$ & $87(4.3 \%)$ & $73(4.0 \%)$ & $14(6.3 \%)$ & 0.12 \\
\hline
\end{tabular}

Values are expressed as absolute numbers (percentages) unless indicated otherwise; ¥Values are expressed as mean (Standard Deviation), BMI: Body Mass Index, ASA: American Society of Anesthesiologists, \&Functional disorders (prolapse, dysmotility) requiring resection, stoma closures with partial colonic resections, polyposis syndromes, colorectal adenoma with resection, infectious enterocolitis, volvulus, fistula-related resections etc. *Transfusion $\geq 1$ unit PRBCs during procedure, ${ }^{€} \mathrm{DM}$ : Diabetes Mellitus, ${ }^{\alpha} \mathrm{HT}$ : Hypertension, ${ }^{\oplus} \mathrm{COPD}$ : Chronic Obstructive Pulmonary Disease,

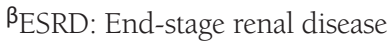

\#Administration within 3 months before surgery 
(Figure 2). Average model-predicted risk rose sharply in the bundle patients from $2.7 \%$ in the lowest risk decile to $64.8 \%$ in the highest risk decile. However, the observed percentages of SSSI remained low across the risk deciles. Observed SSSI was $12.0 \%$ in the second highest risk decile, but no more than $4.0 \%$ in all the remaining deciles. The differences between observed and average predicted risk were highly significant in each of the five highest risk deciles $(\mathrm{p}<0.001)$. Table 4 shows the comparison between pre-bundle and bundle patients selected in a 3:1 frequency matching by wound class (clean and clean/contaminated vs contaminated and dirty), approach (laparoscopic vs open), and BMI groups ( $<20,20-25,25-30$, $30-35, \geq 35)$. The two groups were comparable with respect to patient related factors except for age and administration of chemotherapy. The most striking difference between these groups is the observed SSSI of $13.1 \%$ among the selected prebundle patients and $4.2 \%$ among the selected post-bundle patients $(\mathrm{p}<0.001)$.

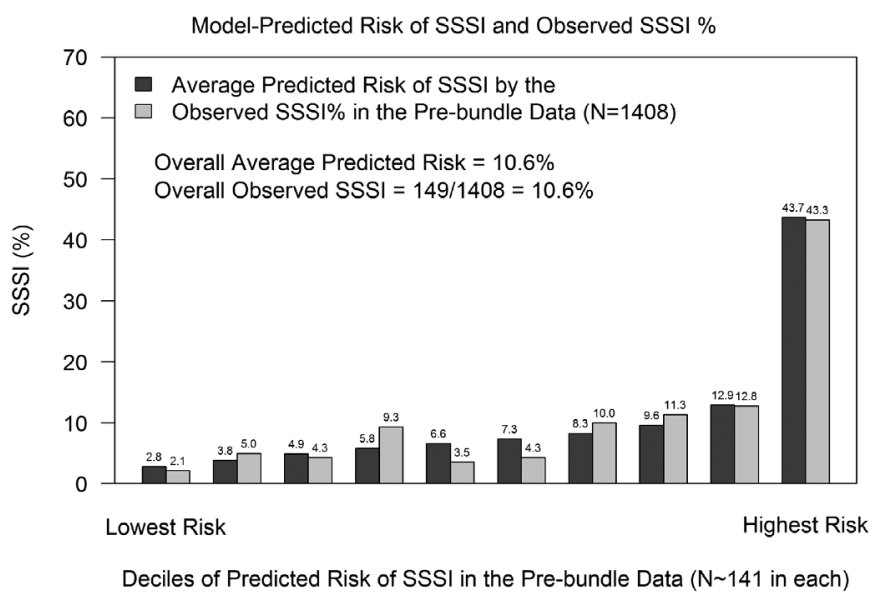

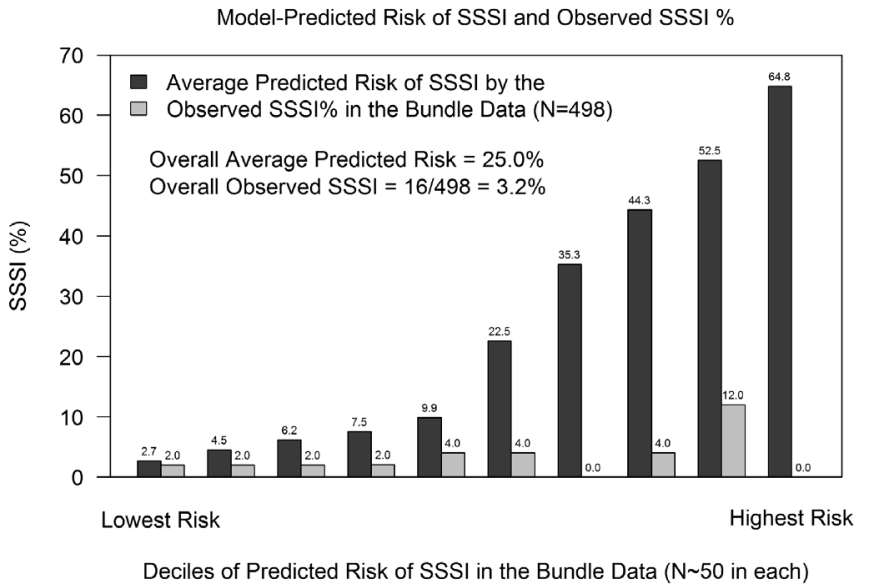

\section{Discussion}

In the current study, we assessed the effect of prevention bundle elements on colorectal patients, who were stratified based on their SSSI risk. The use of a preventive bundle corresponded with a considerable decrease in SSSI rates after colorectal surgery and this reduction was most evident among the high-risk groups. The reliability of the derived risk model was verified by very similar summaries of predicted and observed risk of SSSI in all patients included in the model building. Although pre-bundle and bundle patients have different distributions of some features, such as wound class and type of surgical approach that may impact SSSI outcome; the multivariate modeling directly addressed observed differences between the groups. Furthermore, decrease in SSSI rates is confirmed by frequency matching analysis that constructed on these different characteristics between the groups. Regarding the risk stratification between the pre-bundle and bundle periods, further analysis

Table 2. Results of multivariable model for superficial surgical site infections including all selected risk factors ( $\mathrm{n}=1408$ )

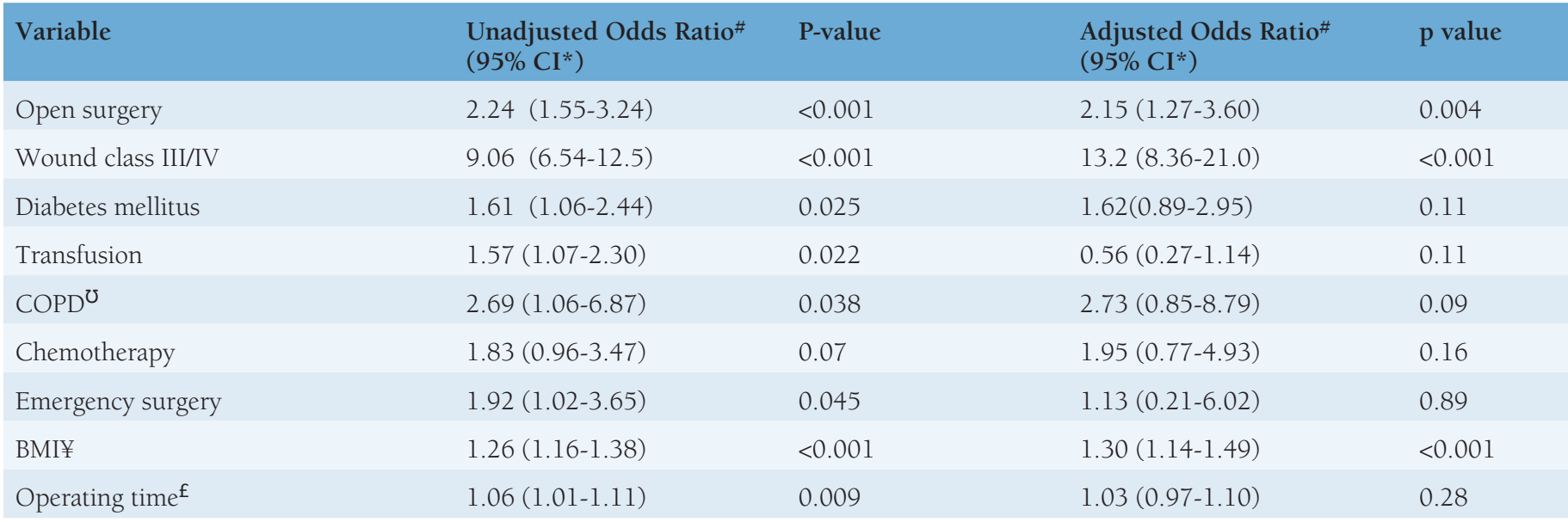

\#Odds ratios are reported for patients who developed superficial surgical site infection relative to those of did not, *CI: Confidence Interval, ${ }^{*} \mathrm{COPD}$ : Chronic Obstructive Pulmonary Disease, ${ }^{\sharp}$ BMI: Body mass index (per $5 \mathrm{~kg} / \mathrm{m}^{2}$ increase), ${ }^{f}$ per 30 minute increase, -ESRD was not included in the model due to too few occurrences. 
demonstrated that the bundle patients clearly did tend to be at lower risk than pre-bundle patients as demonstrated by the higher frequencies within the lower pre-bundle risk deciles. The model itself was created to account for such differences and ensure that observed bundle SSSI was compared to risk estimates specifically tailored to newly designed bundle patients. After checking the risk model by tight correspondence between predicted and observed SSSI rates among pre-bundle patients, the implication, though observational, is that the bundle elements are responsible for the actual reduced risk for bundle patients. Separate risk models should be considered for superficial, deep and organ-space infection based on different pathogenesis. ${ }^{15}$ This is because some operative factors may have impact on organ-space SSI rates with more complex mechanisms. For example, as an unavoidable cause of organ-space SSI, anastomotic leak can be influenced by tissue perfusion, apposition, tension and local spillage and may mask the examining of potential effects of implemented measures on all SSI types, particularly organ-space. In addition to that, the method of conflating different SSIs together weakens the significance of assessment of SSI by combining distinct forms of infectious complications which have quite different potential impacts on care. In our view, investigating the superficial component of SSI can be an optimal proxy for evaluation of direct impact of bundle elements. We then strictly followed superficial SSIs, based on the surveillance criteria classified by the United States CDC.

Table 3. Comparison of pre-bundle patients on whom the risk model was built and the bundle patients used in the risk assessment

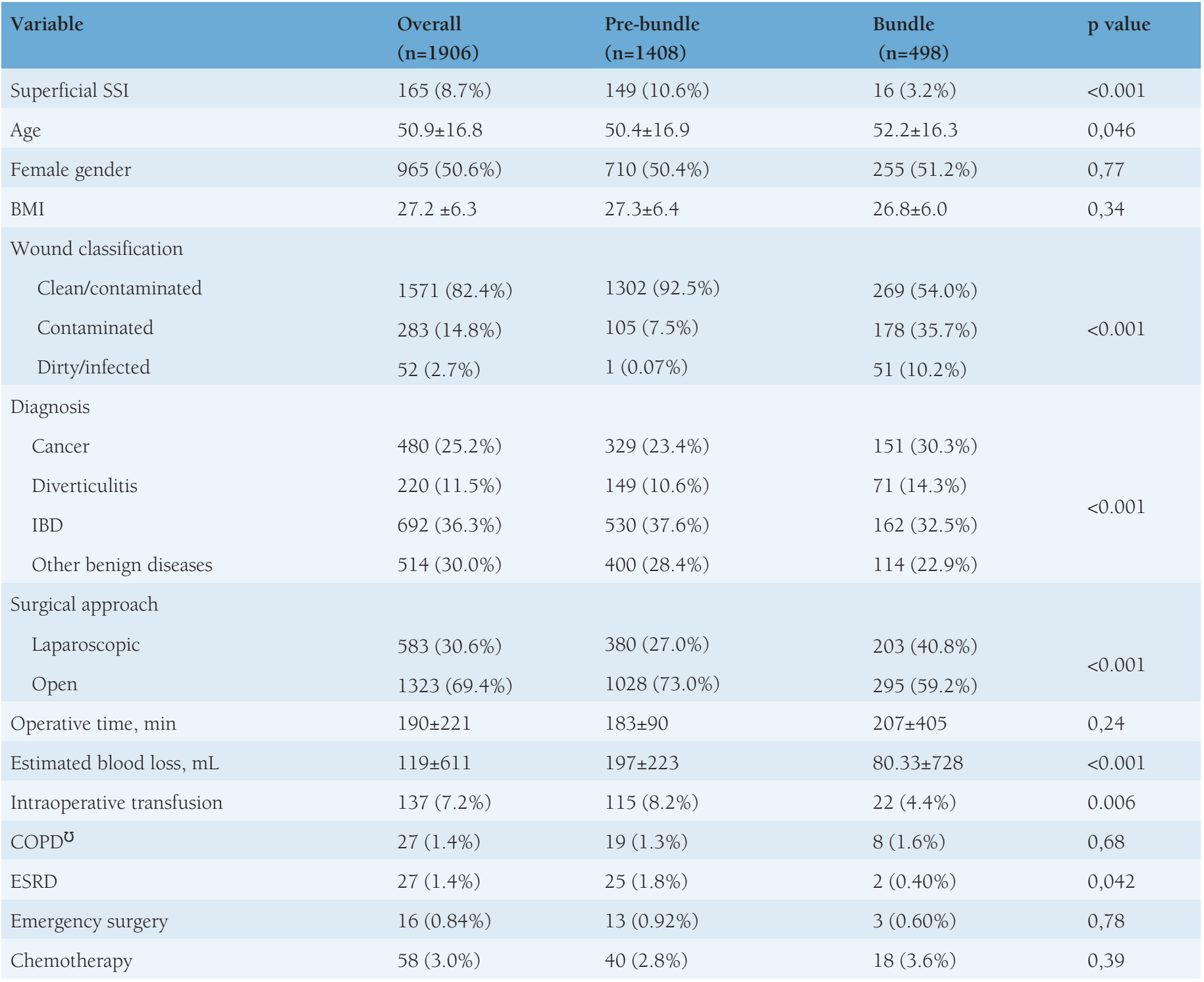

${ }^{\mho}$ COPD: Chronic obstructive pulmonary disease, ${ }^{\ddagger}$ BMI: Body mass index ESRD: End-stage renal disease, IBD: Inflammatory bowel disease 
Previous studies have estimated SSI rates to range between $5 \%$ and $30 \%$ based on operative procedure, method of followup, patient-related risk factors and variability of the SSI definition. ${ }^{1,5,8}$ A superficial SSI incidence of $10.7 \%$, which is reported in our study, is consistent with previous works. ${ }^{5,11,16}$ Simple interventional measures such as negative-pressure therapy ${ }^{17}$ and the use of a subcutaneous drain ${ }^{18}$ have been suggested to reduce SSI rates. Antibiotic-associated measures incorporating timeliness usage, appropriate selection and accurate duration are critical to achieve a substantial reduction in the incidence of SSI. ${ }^{19,20}$ Clinically proven implementations have emphasized the importance of preventive strategies in

Table 4. Comparisons of pre-bundle and post-bundle data frequency matched 3:1 by wound class $\geq 3$, surgical approach (laparoscopic/open) and body mass index group

\begin{tabular}{|c|c|c|c|}
\hline Variable & $\begin{array}{l}\text { Pre-bundle } \\
(\mathrm{n}=1221, \\
75.0 \%)\end{array}$ & $\begin{array}{l}\text { Bundle } \\
(n=407, \\
25.0 \%)\end{array}$ & $\begin{array}{l}\mathrm{p} \\
\text { value }\end{array}$ \\
\hline Superficial SSI & $160(13.1 \%)$ & $17(4.2 \%)$ & $<0.001$ \\
\hline Wound class $\geq 3$ & $183(15.0 \%)$ & $61(15.0 \%)$ & $>0.99$ \\
\hline \multicolumn{4}{|l|}{ Surgical approach } \\
\hline Laparoscopic & $\begin{array}{l}441(36.1 \%) \\
780(63.9 \%)\end{array}$ & $\begin{array}{l}147(36.1 \%) \\
260(63.9 \%)\end{array}$ & $>0.99$ \\
\hline BMI & $27.19 \pm 6.38$ & $26.88 \pm 5.75$ & 0,81 \\
\hline Age, years & $50.2 \pm 17.3$ & $53.2 \pm 16.6$ & 0,002 \\
\hline Female gender & $611(50.1 \%)$ & $213(52.3 \%)$ & 0,43 \\
\hline \multicolumn{4}{|l|}{ Diagnosis } \\
\hline Cancer & $262(21.5 \%)$ & $137(33.7 \%)$ & \multirow{4}{*}{$<0.001$} \\
\hline Diverticulitis & $115(9.4 \%)$ & $49(12.0 \%)$ & \\
\hline IBD & $459(37.6 \%)$ & $121(29.7 \%)$ & \\
\hline Other benign diseases & $385(31.6 \%)$ & $100(24.6 \%)$ & \\
\hline Operative time, min & $183 \pm 89$ & $182 \pm 93$ & 0,63 \\
\hline Estimated blood loss, mL & $197 \pm 215$ & $119 \pm 845$ & $<0.001$ \\
\hline $\begin{array}{l}\text { Intraoperative } \\
\text { transfusion }\end{array}$ & $115(9.4 \%)$ & $21(5.2 \%)$ & 0.008 \\
\hline $\mathrm{COPD}^{\mho}$ & $14(1.5 \%)$ & $8(2.1 \%)$ & 0.48 \\
\hline ESRD & $15(1.4 \%)$ & $2(0.51 \%)$ & 0.18 \\
\hline DM & $83(11.5 \%)$ & $35(8.8 \%)$ & 0.16 \\
\hline Emergency Surgery & $32(2.6 \%)$ & $5(1.2 \%)$ & 0.11 \\
\hline Chemotherapy & $22(2.1 \%)$ & $20(4.9 \%)$ & 0.006 \\
\hline
\end{tabular}

ひCOPD: Chronic obstructive pulmonary disease, ¥BMI: Body mass index ESRD: End-stage renal disease, IBD: Inflammatory bowel disease, DM: Diabetes mellitus, SSI: Surgical site infections maintaining proper glycemic control ${ }^{21}$, normothermia ${ }^{22}$ and oxygen supplementation. ${ }^{23}$ Recently released systematic review has documented the variations in constituents of implemented bundles for patients undergoing colorectal surgery. ${ }^{24}$ However, decision-making on which evidencebased or common-sensed measures will be preferred as a part of the bundle is challenging. Moreover the question of "which subset of patients could benefit the most from targeted interventions" remained unanswered. This impelled us to analyze whether targeting high-risk patients exhibit benefits by risk-modeling. The present study demonstrated a significant decrease in superficial SSI rates with preventive measures and brings the lights to the importance of creation of risk-modeling to test the bundle success. When considering the institutionalized nature of SSIs, the risk-modeling can inspire further researchers. Since traditional mechanical and oral bowel preparation, which constitutes our bundle elements, reduce colonic bacterial load, researchers have investigated their role in decreasing SSSI rates. Systematic reviews have shown that the impact of mechanical bowel preparation on SSI occurrence is controversial, and existing evidence-based outcomes are provided by small sample sizes. ${ }^{25,26,27}$ On the other hand, more potent suggestions are present in large-scale studies for oral antibiotics combined with mechanical bowel preparation, both of which decreased SSI rates. ${ }^{28,29}$ Contaminated/dirty wounds and open surgical approach were identified as independently associated risk factors for SSSI in this report. These well-known factors corroborate with those identified from several published studies stratifying SSI risks. ${ }^{8,11,16}$ Abundance and increased virulence of the colonic flora compared to that of other part of the gut is a well-recognized cause of the increased SSSI risk influenced by contaminated and dirty wounds. Success of our bundle may be explained by incorporating wound protector, which has a major impact on superficial component of SSI. ${ }^{30}$ On the other hand, reported benefits of minimally invasive vs. open surgical approach were also supported by our findings. The present study is limited by some aspects of its design. Firstly, various preventive measures were simultaneously utilized in creating a preventive bundle, so the direct effect of each individual preventive measure on SSSI outcome cannot be easily appraised. Considering the confounding etiologic factors for SSSI, we believe that designing the study based on basic bundle elements could help offset this limitation. Secondly, the retrospective nature of the study did not allow for a comprehensive analysis of other evidence-based interventions that can be used to target SSSI rate reduction after colorectal surgery. Although our proposed strategy targeting high-risk colorectal patients with respect to implementation of preventive measures seems to be conceivably cost-effective, we did not provide cost data. 
The impact of a prospectively designed bundle including extensive evidence-based measures and cost analysis would provide additional information on financial advantages. Efforts and high compliance provided by collaborative and coordinated teams, rather than a unique discipline, are major determinants for sustained reduction in infection rates. ${ }^{3,7}$ It is also critical to consider the suggestions by the United States Centers for Disease Control and Prevention (CDC) for effective monitoring of SSI rates through an active surveillance system. ${ }^{31}$ In conclusion, our study showed that, the implementation of a prevention bundle in patients undergoing colorectal surgery decrease overall superficial SSI rates, but especially in high-risk patients. These data suggest that targeted strategies for infection prevention should be used rather than a blanket policy for all patients.

Acknowledgement: The authors have no conflicts of interest or financial ties relevant to study. Study was presented as podium presentation at American College of Surgeons (ACS) Annual Clinical Congress, Washington, DC, 2013.

\section{References}

1. Keenan JE, Speicher PJ, Thacker JK, et al. The Preventative Surgical Site Infection Bundle in Colorectal Surgery: an effective approach to surgical site infection reduction and health care cost savings. JAMA Surg 2014;149:1045-52.

2. Hedrick TL, Turrentine FE, Smith RL, et al. Single-institutional experience with the surgical infection prevention project in intra-abdominal surgery. Surg Infect (Larchmt). 2007;8:425-435.

3. Dellinger EP, Hausmann SM, Bratzler DW, et al. Hospitals collaborate to decrease surgical site infections. Am J Surg. 2005;190:9-15.

4. Anthony T, Murray BW, Sum-Ping JT, et al. Evaluating an evidence-based bundle for preventing surgical site infection: A randomized trial. Arch Surg. 2011;146:263-269.

5. Lutfiyya W, Parsons D, Breen J. A colorectal "care bundle" to reduce surgical site infections in colorectal surgeries: A single-center experience. Perm J. 2012;16:10-16

6. de Lissovoy G, Fraeman K, Hutchins V, et al. Surgical site infection: Incidence and impact on hospital utilization and treatment costs. Am J Infect Control. 2009;37:387-397.

7. Cima R, Dankbar E, Lovely J, et al. Colorectal surgery surgical site infection reduction program: A national surgical quality improvement programdriven multidisciplinary single-institution experience. J Am Coll Surg. 2013;216:23-33.

8. Tang R, Chen HH, Wang YL, et al. Risk factors for surgical site infection after elective resection of the colon and rectum: A single-center prospective study of 2,809 consecutive patients. Ann Surg. 2001;234:181-189.

9. Institute for Healthcare Improvement (IHI). What is a bundle? Available from: www.ihi.org/resources/Pages/ImprovementStories/What is a Bundle. aspx; Accessed 12/30/2016.

10. Ghuman A, Chan T, Karimuddin AA, Brown CJ, Raval MJ, Phang PT Surgical Site Infection Rates Following Implementation of a Colorectal Closure Bundle in Elective Colorectal Surgeries. Dis Colon Rectum. 2015 Nov;58:1078-82.

11. Serra-Aracil X, Garcia-Domingo MI, Pares D, et al. Surgical site infection in elective operations for colorectal cancer after the application of preventive measures. Arch Surg. 2011;146:606-612.
12. Bull A, Wilson J, Worth LJ, et al. A bundle of care to reduce colorectal surgical infections: An australian experience. J Hosp Infect. 2011;78:297-301.

13. Tillman M, Wehbe-Janek H, Hodges B, Smythe WR, Papaconstantinou HT. Surgical care improvement project and surgical site infections: can integration in the surgical safety checklist improve quality performance and clinical outcomes? J Surg Res. 2013 Sep;184:150-6.

14. Centers for Disease Control and Prevention National Healthcare Safety Network. Surgical site infection (SSI) event. http://www.cdc.gov/nhsn / pdfs/pscmanual/9pscssicurrent.pdf. Accessed August 15, 2015.

15. Blumetti J, Luu M, Sarosi G, et al. Surgical site infections after colorectal surgery: Do risk factors vary depending on the type of infection considered? Surgery. 2007;142:704-711

16. Wick EC, Vogel JD, Church JM, Remzi F, Fazio VW. Surgical site infections in a "high outlier" institution: Are colorectal surgeons to blame? Dis Colon Rectum. 2009:52:374-379.

17. Bonds AM, Novick TK, Dietert JB, Araghizadeh FY, Olson CH. Incisional negative pressure wound therapy significantly reduces surgical site infection in open colorectal surgery. Dis Colon Rectum. 2013;56:1403-1408.

18. Imada S, Noura S, Ohue M, et al. Efficacy of subcutaneous penrose drains for surgical site infections in colorectal surgery. World J Gastrointest Surg. 2013:5:110-114

19. Classen DC, Evans RS, Pestotnik SL, Horn SD, Menlove RL, Burke JP. The timing of prophylactic administration of antibiotics and the risk of surgicalwound infection. N Engl J Med. 1992;326:281-286.

20. Bratzler DW, Houck PM, Workgroup, Surgical Infection Prevention Guideline Writers. Antimicrobial prophylaxis for surgery: An advisory statement from the national surgical infection prevention project. The American Journal of Surgery. 2005;189:395-404.

21. Latham R, Lancaster AD, Covington JF, Pirolo JS, Thomas CS. The association of diabetes and glucose control with surgical-site infections among cardiothoracic surgery patients. Infection Control. 2001;22:607-612.

22. Melling AC, Ali B, Scott EM, Leaper DJ. Effects of preoperative warming on the incidence of wound infection after clean surgery: A randomised controlled trial. The Lancet. 2001;358:876-880.

23. Greif R, Akça O, Horn E, Kurz A, Sessler DI. Supplemental perioperative oxygen to reduce the incidence of surgical-wound infection. N Engl J Med. 2000;342:161-167.

24. Tanner J, Padley W, Assadian O, et al. Do surgical care bundles reduce the risk of surgical site infections in patients undergoing colorectal surgery? A systematic review and cohort meta-analysis of 8,515 patients. Surgery. 2015 Jul;158:66-77.

25. Nelson RL, Gladman E, Barbateskovic M. Antimicrobial prophylaxis for colorectal surgery. Cochrane Database Syst Rev. 2014 May;9:CD001181.

26. Dahabreh IJ, Steele DW, Shah N, Trikalinos TA. Oral Mechanical Bowel Preparation for Colorectal Surgery: Systematic Review and Meta-Analysis. Dis Colon Rectum. 2015 Jul;58:698-707.

27. Güenaga KF, Matos D, Wille-Jørgensen P. Mechanical bowel preparation for elective colorectal surgery. The Cochrane Library. 2011

28. Morris MS, Graham LA, Chu DI, Cannon JA, Hawn MT. Oral antibiotic bowel preparation significantly reduces surgical site infection rates and readmission rates in elective colorectal surgery. Ann Surg. 2015.

29. Kim EK, Sheetz KH, Bonn J, et al. A statewide colectomy experience: The role of full bowel preparation in preventing surgical site infection. Ann Surg. 2014;259:310-314.

30. Reid K, Pockney P, Draganic B, Smith SR. Barrier wound protection decreases surgical site infection in open elective colorectal surgery: A randomized clinical trial. Dis Colon Rectum. 2010;53:1374-1380.

31. Mangram AJ, Horan TC, Pearson ML, Silver LC, Jarvis WR, Hospital Infection Control Practices Advisory Committee. Guideline for prevention of surgical site infection, 1999. Am J Infect Control. 1999;27:97-134. 